\title{
Mind the gap: the use of research in protected area management in Madagascar
}

\author{
Herimanitra Patrick Rafidimanantsoal, Mahesh Poudyal', \\ Bruno S. Ramamonjisoall, Julia P. G. Jones'
}

\author{
Correspondence: \\ Herimanitra Patrick Rafidimanantsoa \\ School of Environment, Natural Resources and Geography \\ Bangor University \\ Deiniol Road \\ Bangor, Gwynedd, LL57 2UW, UK \\ Email: rafidimanantsoa.patrick@gmail.com
}

\begin{abstract}
It is increasingly well recognised that a lot of conservation-related research is not being used to improve conservation practice. However, much of the research in this area has been conducted with conservation managers in high income countries, where the barriers to accessing and using research may be different. We conducted questionnaires $(n=85)$ and face to face interviews $(n=54)$ with managers of protected areas in Madagascar to explore their use of research results. Despite considering research results-including peer reviewed articles, theses, in-house research and research by other organisations-a very useful information source, many managers do not use research results regularly to inform their on-the-ground actions. Instead they tend to rely on experience, or advice from others. The reasons for the low use of research results are many and varied but include barriers to accessing research, especially peer-reviewed publications and reports published by other organisations. Managers also raised concern about the practical relevance of some of the research being conducted in their protected areas. We identify a series of resources which can be useful to managers to improve the access they have to research results and highlight a series of steps which researchers can follow to increase the likelihood of their research being used. We also suggest there is a role for the Malagasy authorities in improving the ways in which research reports-received as part of the conditions of research permits-are shared and archived. Researchers are increasingly aware of the moral imperative that research conducted should be available to inform practice, and protected area managers want access to the best possible information to inform their decisions. With such good intentions, overcoming the gap between research and practice should not be difficult with good communication and essential to improving conservation management in Madagascar.
\end{abstract}

\section{RÉSUMÉ}

L'existence d'un fossé entre la recherche et la pratique est un phénomène de plus en plus reconnu en conservation. Cependant, relativement peu d'études sur ce sujet ont été conduites dans les pays en développement riches en biodiversité. La présente étude explore ainsi l'utilisation des résultats de recherche dans la gestion des aires protégées, principale stratégie de conservation à Madagascar. Des enquêtes par questionnaires $(n=85)$ et des entretiens face-à-face $(n=54)$ ont été menés avec des gestionnaires d'aires protégées. Bien que les gestionnaires considèrent les résultats de recherche, à savoir les publications à comité de lecture, les thèses universitaires ainsi que les recherches internes et externes, comme étant très utiles comme source d'information, peu d'entre eux les utilisent pour motiver des décisions de gestion, à l'exception des recherches menées à l'interne. Les gestionnaires tendent à s'appuyer sur leur expérience ou sur les avis d'autres gestionnaires ou chercheurs. Les facteurs contribuant à la faible utilisation des résultats de recherche sont nombreux et variés mais comprennent en particulier la difficulté d'accès aux publications à comité de lecture et aux recherches externes. Les gestionnaires ont aussi soulevé le fait que certains résultats de recherche effectuée dans leur aire protégée sont peu pertinents à la gestion de celle-ci. Nous avons identifié une série de ressources qui pourraient s'avérer utiles aux gestionnaires pour pallier en partie au problème d'acquisition de résultats de recherche. Nous avons également mis en exergue un ensemble d'étapes que les chercheurs pourraient adopter afin d'augmenter les chances d'utilisation de leur recherche. Par ailleurs, nous soulignons le rôle important que les autorités malgaches ont à jouer dans I'amélioration du mécanisme de partage et d'archivage des rapports de recherche qui leur sont remis conformément aux conditions d'obtention du permis de recherche. Les chercheurs reconnaissent de plus en plus l'impératif moral de mettre leur recherche à disposition des gestionnaires de ressources. Ces derniers, quant à eux, aspirent à accéder aux meilleures sources d'information possibles pour motiver leurs décisions. Avec de telles bonnes intentions, réduire le fossé entre la recherche et la pratique est possible avec une bonne communication et est essentiel pour surmonter les défis de la conservation à Madagascar. 


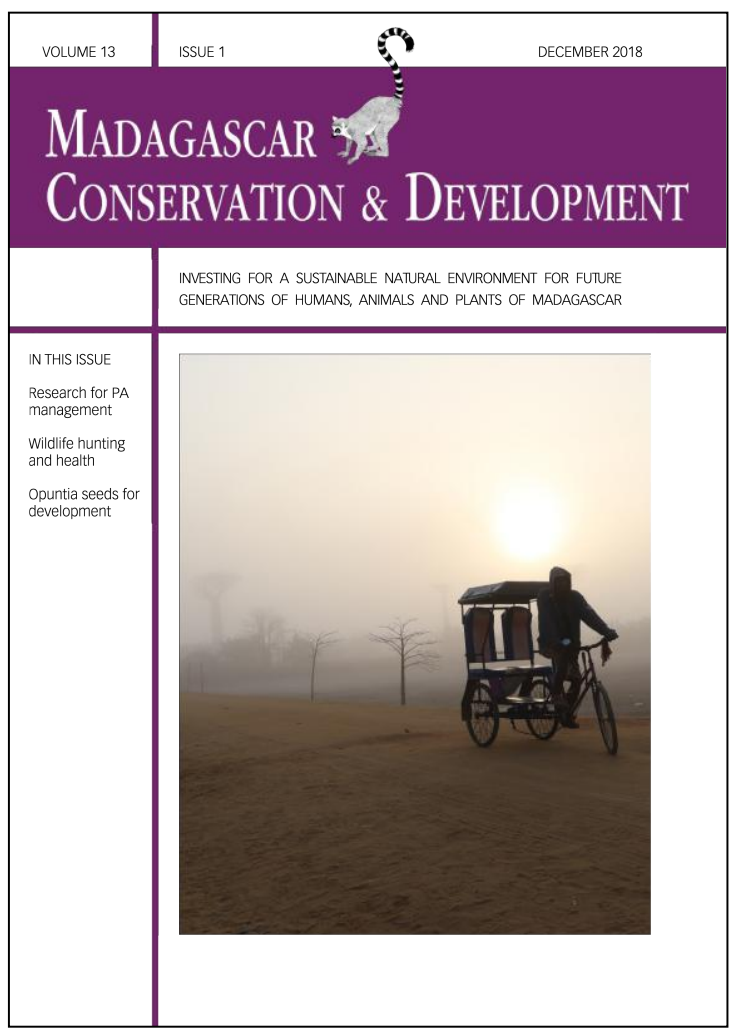

Madagascar Conservation \& Development is the journal of Indian Ocean e-Ink. It is produced under the responsibility of this institution. The views expressed in contributions to MCD are solely those of the authors and not those of the journal editors or the publisher.

All the Issues and articles are freely available at http://www.journalmcd.com

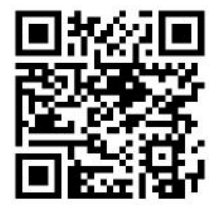

Contact Journal MCD

info@journalmcd.net for general inquiries regarding MCD funding@journalmcd.net to support the journal

Madagascar Conservation \& Development Institute and Museum of Anthropology

University of Zurich

Winterthurerstrasse 190

$\mathrm{CH}-8057$ Zurich

Switzerland

Indian Ocean e-Ink

Promoting African Publishing and Education

www.ioeink.com

Missouri Botanical Garden (MBG)

Madagascar Research and Conservation Program

Missouri Botanical Garden

BP 3391

Antananarivo, 101, Madagascar 


\section{INTRODUCTION}

Conservation science has been widely described as a crisis discipline requiring urgent action (Soulé 1985, Robinson 2006). The purpose of conservation research is to provide knowledge to improve management or policies to address the ongoing biodiversity crisis; making translation of knowledge into action one of conservation's most pressing goals (Segan et al. 2011, Hambler and Canney 2013, Fuller et al. 2014). However, despite the rapid growth over the last two decades in the volume of applied conservation research being conducted (Fazey et al. 2005, Robinson 2006, Roux et al. 2015), it has been regularly noted that much of this research does not go on to influence conservation practice (Knight et al. 2008, Keene and Pullin 2011, Milner-Gulland et al. 2012, Habel et al. 2013). The gap between research being conducted and being used has been explored for a range of research areas including addressing bioinvasion (Bayliss et al. 2013, Kuebbing et al. 2013, Matzek et al. 2014, 2015), bird conservation (Seavy and Howell 2009, Walsh et al. 2015), governance of marine resources (Cvitanovic et al. 2014, 2015), peatland restoration (Anderson 2014), and protected area management (Cook et al. 2010, 2012). There has been quite extensive research into the extent to which research informs the management of protected areas (Pullin et al. 2004, Cook et al. 2010, 2012, Giehl et al. 2017); however, the bulk has been carried out in high income countries where the challenges facing managers may be quite different. Two exceptions are Young and Van Aarde (2011) who explored the use of research in elephant conservation in South Africa, and Gossa et al. (2015) who explored the use of peer-reviewed literature by researchers and practitioners in less developed countries more widely.

A number of authors have highlighted a tension between the research that conservation practitioners need to inform management, and what conservation scientists produce (Bayliss et al. 2012, Cook et al. 2013, Balme et al. 2014). This is at least partly due to the reward structure in research institutions such as universities which promote publications in high impact journals over applied impact (Gibbons et al. 2008, Arlettaz et al. 2010). The high impact journals may require studies of a different scale and concerning types of research questions quite different to those of most value to practitioners (Griffiths 2004, Milner-Gulland et al. 2010, Laurance et al. 2012). There is, however, a big change underway in research with increasing value being put on research which is used. For example, funding bodies such as the UK government research councils require evidence of a planned 'pathway to impact' and the UK government's Research Excellence Framework gives explicit credit for the 'impact' of research (Watermeyer 2014). Increasingly, conservation scientists are looking to base their research on the real research needs of practitioners. There have been a number of attempts to gather and collate research needs of practitioners (Sutherland et al. 2009, 2012, Caudron et al. 2012), and to improve information delivery and communication between researchers and practitioners (Roux et al. 2006, NeBhöver and Timaeus 2013, Young et al. 2014, Chapman et al. 2015).

Protected areas are rapidly expanding as a conservation approach (Jenkins and Joppa 2009, Watson et al. 2014). Their goals and objectives are increasingly complex; as well as providing habitat for threatened species and conserving iconic landscapes, they are also expected to contribute to social objectives (Watson et al. 2014). However, despite these good intentions, managing protected areas so that biodiversity objectives are met without harming local communities is challenging (Brockington and Wilkie 2015). The International Union for Conservation of Nature (IUCN) has developed the following protected area categories (Dudley 2008): Category la: Strict Nature Reserve, Category Ib: Wilderness Area, Category II: National Park, Category III: Natural Monument or Feature, Category IV: Habitat/Species Management Area, Category V: Protected Landscape/Seascape, Category VI: Protected Area with sustainable use of natural resources. Category $V$ is currently more and more widespread but also stirs much debates (Shafer 2015). Increasingly, conservation research is moving beyond studies of threatened species and habitats and is tackling issues such as equity, local livelihoods, and land tenure (Mace 2014, Marvier 2014, Pooley et al. 2014).

Madagascar is a country of global importance to conservation due to its incredible biodiversity and the numerous and pressing threats imperilling this biodiversity (Dinerstein et al. 2017). In 2003 the president of Madagascar decreed that the country would triple the extent of its protected area network (Gardner et al. 2013), i.e., up to $10 \%$ of the national territory. This led to a major scientifically-driven process for identifying priorities for the establishment of new protected areas (Kremen et al. 2008). The expansion has been largely achieved, and by 2015, 59 of new protected areas had been gazetted. These new protected areas, and Madagascar's existing network of protected areas, some of which date back to the colonial era, face many challenges in terms of conserving biodiversity without undermining local welfare (Raik et al. 2008, Brimont et al. 2015, Poudyal et al. 2016). In the new protected areas, however, poverty alleviation is more explicitly listed as a goal (Gardner et al. 2013, Shafer 2015). There is an enormous amount of research conducted in Madagascar every year by academic institutions-both those based in Madagascar and from overseas-and some non-governmental organisations (NGOS). However, there is very little information available on how this research is used to contribute to the management of protected areas, and what the barriers are for more use.

In this paper, we attempt to understand the sources of information used by managers of protected areas in Madagascar, particularly the research results, using questionnaires and semi-structured interviews with conservation managers from all over the country. These are the people making decisions every day which affect both the biodiversity for which they have management responsibility and the lives of local communities who may depend on the natural resources within the protected areas. We explore (i) how useful managers feel different sources of information are to guide their management actions, (ii) the extent to which different information sources are used to inform their management actions, (iii) how they access research and (iv) what barriers they perceive to using research more in their management. We then discuss practical ways to overcome these barriers.

\section{METHODS}

DEFINITIONS. We developed information types based on the categorisation by cook et al. (2012). We consider three sources of information: (i) research, including peer-reviewed literature, academic theses, in-house reports and external reports; (ii) experiential, including personal experience, advice from managers, advice from specialists; or (iii) intermediate, including management plans, manuals and guidelines.

In this paper, research results refer to any output of a scientific investigation or synthesis carried out by researchers and fol- 
lowing the research process. Any discipline in the natural or socia sciences pertaining to conservation is considered, such as ecology, biology, sociology, governance, politics, climate change, systems research, and management sciences. Such breadth is necessary given the complexity of nature conservation today. Our definition of research results is not limited to peer-reviewed publications (cf. Gossa et al. 2015) but also includes the research grey literature (technical reports, theses, newsletters written by practitioners) (Aina 2000). We include this wider definition of research results because the grey literature is important, is less subject to publication bias and may include more practice-oriented results than the peer reviewed literature (Haddaway and Bayliss 2015). However, the risk of using the grey literature for decision making or to inform management is that the quality of the evidence may be weaker.

There are basically two concepts of research utilisation: that of outcome and that of process (Rich 1997). In this study we conceived research utilisation as a process which involves research results being acquired, read, understood or not, and some action is taken by the user (Rich 1997). The barriers to research use are therefore the barriers encountered at each step of the process.

SAMPLING APPROACH. Our target population was conservation professionals working in protected areas who have responsibility for decision-making concerning conservation actions These site-based professionals, hereafter referred to as managers, may hold a general (e.g., park director) or a more specific (e.g., conservation officer) managerial position. These people design and update the management plan of the protected area they are responsible for. As of 2015, we considered 100 protected areas in Madagascar with a clear promoter, distributed into six categories (Table S1). Strict Nature Reserve, National Parks and Special Reserves (category I, II and IV, respectively, in the IUCN categorisation) are managed by Madagascar National Parks (MNP), a parastatal agency. Natural Monuments, Protected Landscapes, and Natural Resources Reserves (category III, V and VI, respectively) are managed by national or international non-governmental organisations or private companies.

For organisations managing more than one protected area, we initially approached the central office (for example Madagascar National Parks and some of the larger NGOs such as Conservation International and Durrell Wildlife Conservation Trust), introduced our research and obtained permission to contact sitemanagers and their contact details. For smaller organisations or where central office did not respond to our approach, we used our personal and professional network to contact some protected area managers directly.

We contacted site-based managers by email and/or phone initially and invited them to complete our questionnaire and/or take part in a more in-depth face-to-face interview. In the course of the research we visited protected areas throughout the country except the south east and north east. We found that personal visits were very important for generating interest in the research.

QUESTIONNAIRE. The majority of the results presented below comes from our questionnaire survey (Supplementary Material 2). The questionnaire development was informed by previous similar studies (e.g., Pullin et al. 2004, Cook et al. 2010, Gossa et al. 2015) and adjusted after piloting when necessary. We predominantly used rating scales. The questionnaire collected demo- graphic data, and asked participants to rate how often and how useful different information sources were to guide management decisions, how they access research results, and how often they have experienced a series of known, literature-based barriers when using research evidence.

We conducted a pilot survey with five conservation managers working for NGOs in Madagascar based in the capital city (testing both the English and French versions). Based on their feedback, some questions were reformulated and the vocabulary simplified. The final version was in French as it is easier for our target population to understand our topic and the terms we used in the questionnaire if these were in French. We sent the questionnaire via email as an attachment to all primary site-based contacts (typically the Park Director) of each of the 100 protected area we considered in this study; they were encouraged to share with colleagues with whom they share management responsibility for the park. In total 85 questionnaires from 53 protected areas were returned. Questionnaires were completed between June and November 2016. It is difficult to give a precise return rate given that the population size of potential participants (those with management responsibility for a protected area) is unknown. However we estimate the potential participants to be between 200 and 300 , assuming 2 to 3 potential participants per protected area. With these estimates, the return rate lies between 28 and $42 \%$.

We used diverging stacked bar charts to display the patterns for categorical variables with semantic differential levels such as frequency of use, perceived usefulness, ease of access, and barriers to research use using the package $\mathrm{HH}$ (Heiberger and Robbins 2014). We used the R statistical software (R Core Team 2017) to produce the charts.

INTERVIEWS. We also conducted semi-structured interviews in person that focused around the question "In your experience, what are the barriers you have encountered when it comes to using research results in your work?". These allowed us to capture the barriers not covered in the questionnaire and to add depth to our understanding of the barriers to research use. The barriers to research use are therefore the barriers encountered at each step of the process. The semi-structured interviews were done using a blend of Malagasy and French, which is very common in technical conversations.

These semi-structured interviews ( $n=54$ from 29 protected areas) were conducted in person with managers of protected areas at their place of work (Figure S3). The participants in the interviews were selected based on a combination of the logistics of accessing particular protected areas, and managers' willingness to be interviewed. Amongst the participants we interviewed, $87 \%$ also filled out the questionnaire. We used thematic analysis (Braun and Clarke 2006) to explore the barriers pertaining to knowledge production, access, understanding, and implementation using research utilization as a process of our analysis framework.

RESEARCH ETHICS. This research was approved under the Bangor University research ethics framework. We obtained informed consent from everyone who took part in the research by explaining the purpose of the research and how the research results would be used. We emphasised that they were not obliged to answer our questions and that we would not be passing their responses on to anyone else (including senior people in their organisations). We emphasised that we would not report the results 
in a way which made it possible to identify the responses of individuals.

\section{RESULTS}

DATA DESCRIPTION. A total of 85 managers returned the questionnaires (42 from managers working in parks and reserves managed by MNP and 43 from those working in protected areas managed or co-managed by NGOS) representing 53 protected areas. In terms of educational attainment, $80 \%$ of the managers who returned the questionnaire have postgraduate degrees (74\% Masters and 6\% Ph.D.). Participants' work experience in conservation or environmental management, excluding formal education, ranges from 1 to 31 years with a mean of 12 years.

We interviewed 54 participants ( 26 worked for MNP and 28 for NGOs) from 29 protected areas. Three-quarters (75\%) of the managers we interviewed have a Masters degree. Their work experience in conservation or environmental management ranges from 1 to 25 years with a mean of 11 years. There were 47 participants who both returned the questionnaires and were interviewed.

DO MANAGERS PERCEIVE RESEARCH RESULTS AS USEFUL TO INFORM THEIR ACTIONS? Managers perceived all information (including our four categories of research) to be useful to their decision-making (Figure 1). In-house and external research results are perceived as the most useful compared to academic outputs, although not by much.

WHAT INFORMATION SOURCES ARE MANAGERS USING? EXeriential sources of information (especially personal experience or advice from managers) is the main source of information used by research managers (Figure 2). Management plans and manuals and guidelines are also widely used. Research results vary in how widely they are used: commissioned studies and inhouse research are used but external research, theses and especially peer-reviewed publications are seldom used (Figure 2). The difference between the perceived usefulness of peer-reviewed research (Figure 1) and the extent to which it is used (Figure 2) is especially noteworthy.

HOW EASILY CAN RESEARCH RESULTS BE ACCESSED BY MANAGERS? There are clear differences in the accessibility of different types of research results. Managers find it relatively straightforward to access in-house research from their own organisation, although it is still surprising to see some found it difficult. However, accessing other forms of research results (theses, external research results or peer-reviewed publications) is difficult for the majority of respondents (Figure 3).

HOW DO MANAGERS OBTAIN RESEARCH RESULTS? When aC-

tively searching for research results, managers primarily ask their colleagues who are researchers or specialists, browse the web, and use internal documentation (their personal collection or organisation library) (Figure 4). The importance of professional networks is particularly notable. Online fora and research databases are less used, although it is unclear whether this is due to a lack of awareness of their existence and purpose by managers or due to other factors.

There are of course occasions when research results are received by managers who were not actively searching for them.

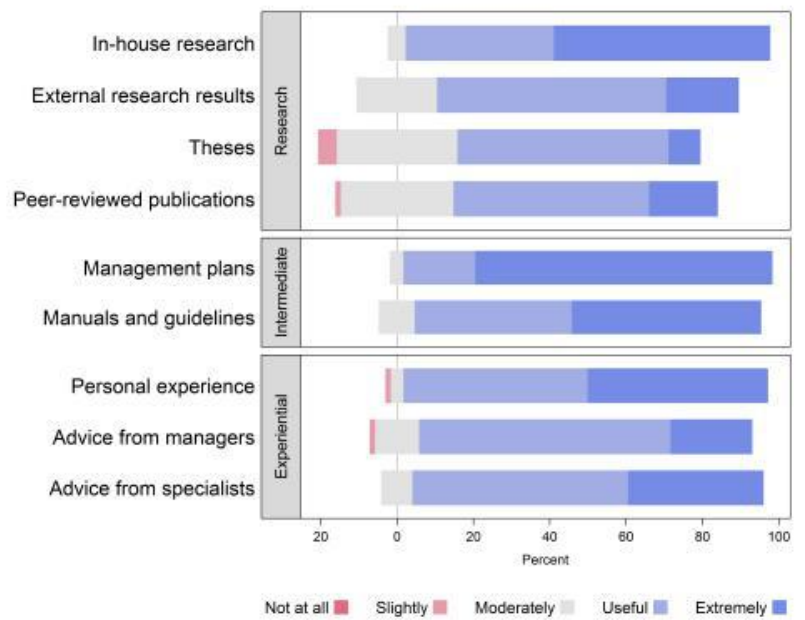

Figure 1. How useful protected area managers in Madagascar perceive various information sources are to inform their actions $(n=85)$.

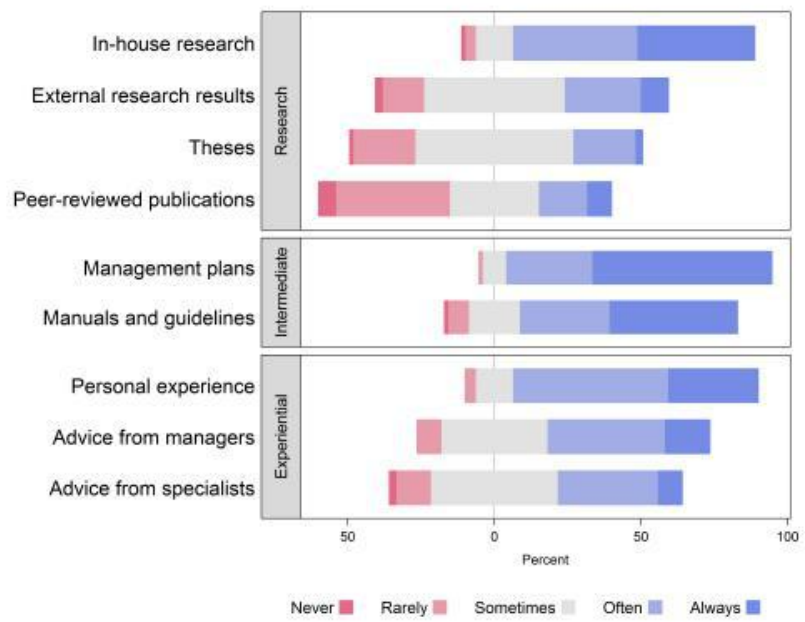

Figure 2. How often protected area managers in Madagascar use various information sources to inform their actions $(n=85)$.

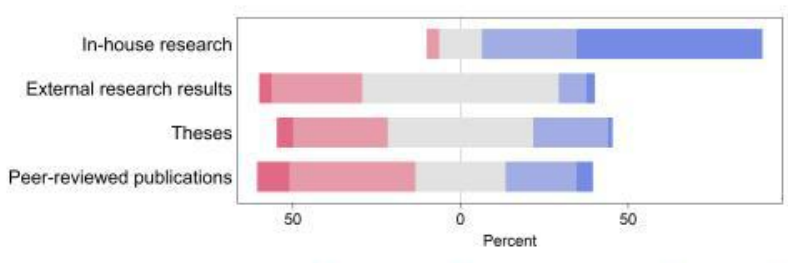

Very difficult || Quite difficult i| It depends

Figure 3. Ease of access to different types of research results by protected area managers in Madagascar $(n=85)$.

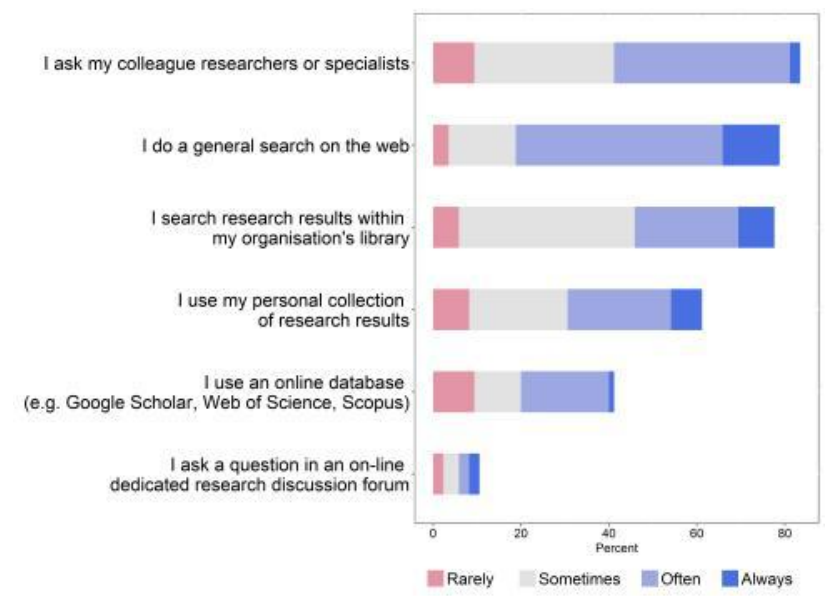

Figure 4. How protected area managers in Madagascar search for the research results they need $(n=85)$. 
Research results are received by managers through colleagues who send them research results, or mention it during workshops (Figure 5). Social media, journal alerts or formal professional networks (e.g., Madagascar Environmental Justice Network) are less used. This again highlights the importance of managers' informal professional networks for obtaining research results.

WHAT ARE THE BARRIERS TO THE USE OF RESEARCH RESULTS? Several managers suggested that one of the reasons they do not use research results is that they felt there was limited research of relevance to them and their needs. There was a tendency among managers making this point to talk about the lack of research at their specific site (implying that they are particularly interested in research carried out at their site, rather than research at other sites on relevant themes). The lack of research was particularly highly reported by managers of newly established PA but the same issue was also reported by some long-established PAs (especially where poor roads or insecurity means few researchers visiting).

"In our case, the research results themselves are lacking" (Director of a Protected Area with sustainable use of natural resources (category VI), Eastern Madagascar)

"The problem with our PA is that there are very few researchers who come here because the roads are so challenging. The last time there were researchers here was in 2008." (Director of a Habitat/Species Management Area (category IV), Eastern Madagascar)

Sometimes it is not a case of there not being any research, but that managers do not perceive that the research which has been conducted is relevant to their needs. There is a sense that the research which researchers like to do (and perhaps which feeds into large scale analysis) has limited management relevance at a specific site.

"But there are results that we don't know really what to do with these. Take research on ants for example. It's true that it is interesting to know about the species that exist and their ecology and so on, but for us managers what really matters is how we can measure our management effectiveness of the PA. Lemurs monitoring for example speaks to us directly as the population dynamics reflects our management effectiveness. In short, [we need] research that is important to us and that is related to our target

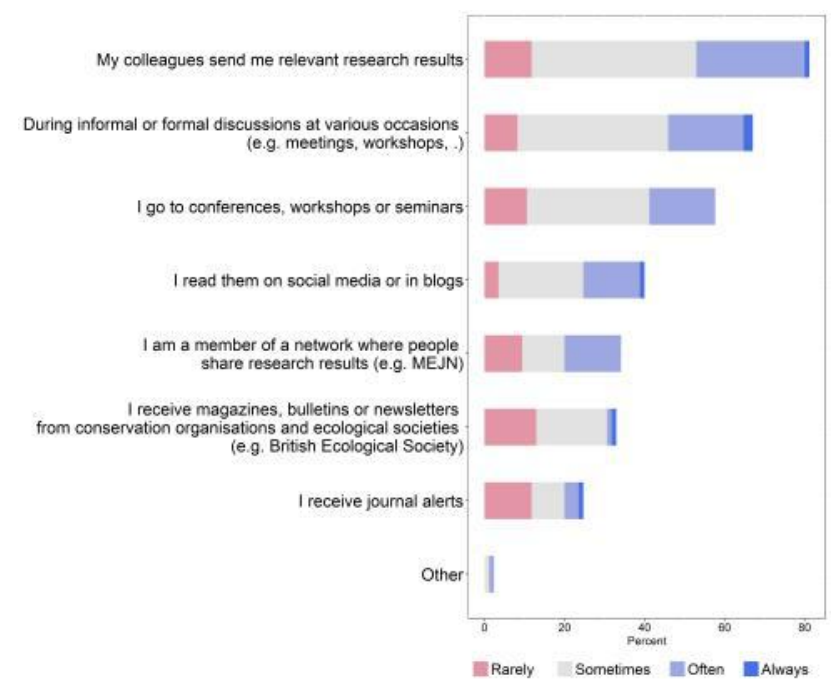

Figure 5. How protected area managers in Madagascar hear about research results $(n=85)$. species or indicator species." (Director of a Habitat/Species Management Area (category IV), Northern Madagascar)

In many cases, even if relevant research had been conducted, managers were not able to access research. A very common complaint among the managers interviewed was that researchers do not give the results back. Given the challenges of accessing peer-reviewed publications, reports returned by researchers to managers are invaluable.

"If there are, say 50 research investigations done in our PA, I'd say only two or three reach us back. That is one big problem. You see the process starts with the institution that delivers or grants research permits. If that institution is not enforcing the restitution of research results, then researchers simply disregard us". (Director of a Habitat/Species Management Area (category IV), Northern Madagascar)

The importance of researchers returning reports (ideally in French), and any published papers, to managers was also highlighted by our questionnaire data (Figure 6). The most important barrier reported is that organisations lack subscriptions to journals. It is interesting to note that managers also report problems in accessing external research results (e.g., reports carried out by a different organisation on a theme of interest to the managers).

The language of higher education in Madagascar is French and all managers are fluent in French while only a sub-set can read English (the language of many international journals). Just over a quarter of respondents considered the English language to be an issue. The language used in reports presenting research results (both in terms of writing in languages which are understood locally and avoiding technical jargon) are also important for the managers to get buy in for implementation of research results locally.

"One of our biggest difficulties is to translate the research findings into terms that local partners can apprehend." (Director of a Protected Landscape (category V), Southern Madagascar)

Finally, there are barriers occurring at the implementation stage, and these include the lack of local capacity, budget constraint, and lack of organisational support.

"Another barrier is also financial resources, because often ... in our case for example, we function as a project, so if the recommendations from a relevant piece of research are not planned within the project there is hardly anything we can do about it." (Director of a Protected Area with sustainable use of natural resources (category VI), Eastern Madagascar)

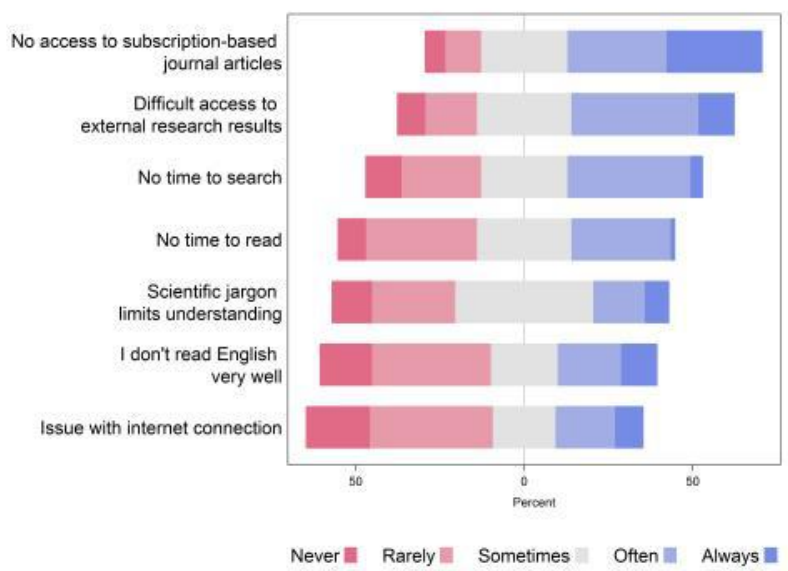

Figure 6. Barriers to research use experienced by protected area managers in Madagascar $(n=85)$. 


\section{DISCUSSION}

MANAGERS CONSIDER RESEARCH RESULTS BUT FACE MANY

CHALLENGES. Managers of protected areas in Madagascar value all sources of information open to them for informing their practice. These include research-based information (found in peer-reviewed research and in-house research most greatly valued), experiential information (from personal experience, advice from specialists and advice from senior colleagues), and intermediate information such as management plans, manuals and guidelines. However, despite the value placed on research results by managers, it is interesting to note that most categories of research results (the exception being in-house research) are not widely used. For example, a large majority of managers who responded to our survey never or rarely uses peer-reviewed publications. The fact that research results are relatively less used compared to experiential and intermediate sources of information in guiding management actions has been found by a number of other studies exploring the use of conservation evidence (e.g., Pullin et al. 2004, Sutherland et al. 2004, Cook et al. 2013).

There are two plausible reasons why research results are not more widely used by protected area managers in Madagascar. First, not every aspect in managing a PA requires research-based information. Indeed, protected area management contains a great deal of routine activities and urgent problem solving that does not require research-based information. The second reason why research based information is seldom used is due to barriers to research use. In our experience, these two explanations are not mutually exclusive but rather co-occur in the context of protected area management.

By exploring the barriers to research use based on both qualitative and quantitative data we have built up a picture of why managers do not use research results more often in their practice. Firstly, there is the issue that much of the research conducted by researchers does not appear relevant to the management needs of the protected area managers. However physically gaining access to research results is clearly a significant issue for many managers. It is clear that managers are making use of their networks to access research results (with the most common means of searching for research results and receiving research results being asking colleagues, researchers or specialists). This approach and searching their institution's library and use of their own personal collection is particularly important as many research results are published behind a paywall that protected area managers cannot access (lack of access to subscription journals was reported as the top barrier to accessing research results). It is worrying that research conducted by other organisations in Madagascar was perceived as so difficult to access; qualitative interviews suggest there is a perception that organisations do not like to share their work even when it could help other organisations. There are of course other reasons why research results are difficult to access-time (to access and read results), challenges with language, and access to the internet are all commonly reported issues. Finally, even where relevant research has been conducted, and the managers can access it and understand it, sometimes budget or capacity constraints mean the results do not influence practice.

WHAT COULD BE DONE TO IMPROVE THE USE OF RESEARCH RESULTS IN MADAGASCAR? There is evidence that the conservation practice and policy community are evidence com- placent (Sutherland and Wordley 2017). Our discussions with managers across Madagascar suggest that many managers are indeed motivated to use research results but maybe unsure how to progress. We argue that managers are more likely to use research results if these are findable, relevant, accessible, and understood (although resource constraints will also play an important role in influencing the extent to which research results are put into practice). Considering the findings of this study, we propose the following practical recommendations to improve the use of research results in PA management in Madagascar.

MAKING RESEARCH MORE RELEVANT TO MANAGERS' NEEDS.

Our results show that in-house research is the most common type of research used by protected area managers in Madagascar. In-house research is designed to respond to management needs as is commissioned by the organisation itself or one of its partners. Most research conducted in Madagascar is initiated by researchers themselves and it is perhaps not surprising that managers feel much of it lacks relevance. This lack of management relevance of much conservation research is a well-documented issue (Milner-Gulland et al. 2010, Laurance et al. 2012, Matzek et al. 2014, Chapman et al. 2015).

While there will always be researchers wishing to conduct research which does not have obvious and direct applied relevance (and it is important to note that such research may still be useful in longer term or for larger-scale decision making), there are increasing numbers of researchers very keen to ensure their research is useful. Therefore, researchers require mechanisms for learning about the research needs of managers and may then be able to adapt their research questions to provide useful information to managers. There is currently no clear mechanism for researchers to know managers' needs in Madagascar. The simplest way maybe for managers to post their research needs on their organisation's website, so that it can be used to inform the agenda of the research community. There have been a number of exercises where researchers and practitioners teamed up to produce lists of top research questions (Sutherland et al. 2006, Pretty et al. 2010, Rudd et al. 2011). Such schemes have been quite influential on research agendas (Dicks 2013, Dicks et al. 2013) and perhaps such an exercise could be conducted in Madagascar; bringing together protected area managers and researchers.

HELPING MANAGERS ACCESS RESEARCH RESULTS. Web platforms like ResearchGate and Academia.edu (where researchers share copies of their published work) and Sci-Hub (which uses passwords shared by academics to download and publically archive copies of academic articles) are increasingly offering ways for those without subscriptions to scientific journals to access research results (Bohannon 2016). The conservation community in Madagascar has additionally benefited from the work of those running the Madagascar Environment Justice Network who share particularly relevant articles on an online forum (often with accompanying discussion and debate). Theses from many universities internationally are also increasingly available online; including most theses from the University of Antananarivo defended since 2002. However, our research suggests that many managers are not aware of these ways of accessing research results. Such information could be offered by organisations as part of the training they provide their managers to increase their ability to access research results of interest to them. 
WHAT CAN RESEARCHERS DO? Managers are short of time, struggle with internet access and some (though far from all) struggle with reading research published in English or which uses technical language. Therefore, the research community have a clear role to play in improving the accessibility of research results to protected area managers in Madagascar. As part of the terms of their research permits, researchers are required to return results in the form of reports to the relevant ministry, which typically is the Ministry of Environment, Ecology and Forests, in the case of conservation research. However, anecdotal results suggest these often do not make it to the hands of the protected area managers in the sites the researchers worked because either they are not produced or they are not passed on. They are also of variable quality and value to managers because they are produced before the research has been fully analysed, or because they do not explicitly make the management relevance clear. As researchers, we have an obligation to ensure our research is available to be used by society.

Here we present our view, informed by our findings on the barriers to research use by protected area managers in Madagascar, of the steps all researchers should take: (i) Involve managers in the research: Sharing results with potential stakeholders including protected area managers is not something which should happen at the very end of the research process. Researchers should make the effort to discuss the research with managers while the research is underway (ideally even inviting them to the field to get involved in the research). The more potential users of research understand the research conducted, the more likely they are to apply its lessons (Hulme 2014). (ii) Share preliminary results: Researchers should ensure they do a verbal presentation of results (this may be a formal presentation to the protected area team or simply a sit down chat with one or two key people) before they leave the field so any preliminary results can be understood and potentially impact practice as soon as possible. (iii) Ensure final reports are useful and accessible: When producing final reports, researchers should consider the audience and ensure that they make management relevance clear. This may mean producing a specific report aimed at managers in Madagascar, rather than simply using a report produced for funders. Wherever possible they should ensure a copy of their reports gets back to the field sites where they operate. Often data continues to be used in publications for a long period of time after an initial report is published and researchers should make every effort to return these papers ideally with a covering abstract in French where the paper is published in English so managers see how the research conducted in their protected area went on to be used. Most protected area managers in Madagascar have email even if internet access is intermittent. This makes returning reports and papers to protected areas managers much easier. (iv) Make all research open access: Researchers should also be considering about the wider accessibility of articles they publish. Publishing in open access journals such as Madagascar Conservation \& Development wherever possible, putting articles up on servers such as ResearchGate or Academia.edu, or in university repositories all increase the value of research to society. There is growing evidence that such practices, perhaps unsurprisingly, also increase the citations a paper receives (Gargouri et al. 2010, Niyazov et al. 2016). As academics are increasingly judged by metrics such as citations (Lane 2010, Burrows 2012), this may act as extra incentive to make research available.
WHAT CAN THE MALAGASY AUTHORITIES DO? Where reearch permits have been granted for research in terrestrial protected areas, the Ministry collects final reports. These are returned in hard copy to the protected area where the research was conducted. However, such reports may go missing, may not be well archived at the site, and also, may have relevance beyond the site where the research was carried out. For these reasons, we strongly encourage the Ministry to develop an electronic submission and archiving system with a searchable web-interface. Strong incentives need to be put in place to ensure that researchers who have been granted a research permit do return their final reports in both printed and digital forms. For example, new applications should not be granted without a check that previous research reports have been submitted.

Funders of research in many countries are starting to request that raw data is archived to maximise the value of research for future research or management (Molloy 2011). The Malagasy government may consider moving towards requesting that research projects archive data in publicly available repositories. However, it is important to note that data cleaning and preparation for archiving can take many months or even years in the case of biological inventories where taxonomic work is needed. Therefore, it may be difficult to require archiving but it should be explicitly encouraged.

\section{CONCLUSION}

Managing a protected area in Madagascar to maintain its incredible ecological value while considering the livelihoods and needs of surrounding populations must be one of the most difficult, but also most important, jobs in conservation. In order to increase efficiency and efficacy, Madagascar's protected area managers therefore need access to the best possible information to inform their decisions. Increasing communication between researchers and protected area managers could increase the applied relevance of research conducted in Madagascar's protected areas. There is much that researchers can do to make their research more likely to be used and if all researchers in Madagascar (whether students or leaders of sizable research projects) were to follow the steps we outline here, we argue that much more of the research conducted in Madagascar could contribute to effective conservation management. This would benefit Madagascar's protected area managers, researchers themselves, and most importantly the protected areas and their local populations.

\section{ACKNOWLEDGEMENTS}

Thanks to Madagascar National Parks, Conservation International, Missouri Botanical Garden, Madagasikara Voakajy, Fanamby, Blue Ventures, Kew Botanical Gardens, Durrell Wildlife Conservation Trust, Groupe d'Études et de Recherche sur les Primates (GERP), ESSA-Forêts, Worldwide Fund for Nature, Duke Lemur Center, Managed Resources Protected Areas project and all the individuals who filled out questionnaires or agreed to be interviewed. Thanks to James Gibbons for help with analysis. This study was funded by the Ecosystem Services for Poverty Alleviation programme as part of a fellowship to Patrick Rafidimanantsoa (FELL2014-108). We also thank the p4ges project (NE/K010220-1), Dr Chris Sandbrook, and the Cambridge University MPhil in Conservation Leadership course. We also thank the two reviewers for their invaluable comments. 


\section{REFERENCES}

Aina, L. O. 2000. Grey literature and library and information studies: a global perspective. International Journal on Grey Literature 1, 4: 179-182. <https://doi.org/10.1108/14666180010382590>

Anderson, P. 2014. Bridging the gap between applied ecological science and practical implementation in peatland restoration. Journal of Applied Ecology 51, 5: 1148-1152. <https://doi.org/10.1111/1365-2664.12258>

Arlettaz, R., Schaub, M., Fournier, J., Reichlin, T. S., Sierro, A., Watson, J. E. M. and Braunisch, V. 2010. From Publications to Public Actions: When Conservation Biologists Bridge the Gap between Research and Implementation. Bioscience 60, 10: 835-842. <https://doi.org/10.1525/bio.2010.60.10.10>

Balme, G. A., Lindsey, P. A., Swanepoel, L. H. and Hunter, L. T. B. 2014. Failure of research to address the rangewide conservation needs of large carnivores: Leopards in South Africa as a case study. Conservation Letters 7, 1: 3-11. <https://doi.org/10.1111/conl.12028>

Bayliss, H., Wilcox, A., Stewart, G. B. and Randall, N. P. 2012. Does research information meet the needs of stakeholders? Exploring evidence selection in the global management of invasive species. Evidence and Policy 8, 1: 37-56. <https://doi.org/10.1332/174426412x620128>

Bayliss, H., Stewart, G., Wilcox, A. and Randall, N. 2013. A perceived gap between invasive species research and stakeholder priorities. NeoBiota 19: 67-82. <https://doi.org/10.3897/neobiota.19.4897>

Bohannon, J. 2016. The frustrated science student behind Sci-Hub. Science 352, 6285: 511. <https://doi.org/10.1126/science.352.6285.511>

Braun, V. and Clarke, V. 2006. Using thematic analysis in psychology. Qualitative Research in Psychology 3, 2: 77-101. <https://doi.org/10.1191/1478088706qp0630a>

Brimont, L., Ezzine-de-Blas, D., Karsenty, A. and Toulon, A. 2015. Achieving conservation and equity amidst extreme poverty and climate risk: The Makira REDD+ project in Madagascar. Forests 6, 3: 748-768. <https://doi.org/10.3390/f6030748>

Brockington, D. and Wilkie, D. 2015. Protected areas and poverty. Philosophical Transactions of the Royal Society B 370, 1681: 20140271. <https://doi.org/10.1098/rstb.2014.0271>

Burrows, R. 2012. Living with the h-index? Metric assemblages in the contemporary academy. The Sociological Review 60, 2: 355-372. <https://doi.org/10.1111/j.1467-954x.2012.02077.x>

Caudron, A., Vigier, L. and Champigneulle, A. 2012. Developing collaborative research to improve effectiveness in biodiversity conservation practice. Journal of Applied Ecology 49, 4: 753-757. <https://doi.org/10.1111/j.1365-2664.2012.02115.x>

Chapman, J. M., Algera, D., Dick, M., Hawkins, E. E., Lawrence, M. J., et al. 2015. Being relevant: Practical guidance for early career researchers interested in solving conservation problems. Global Ecology and Conservation 4: 334-348. <https://doi.org/10.1016/j.gecco.2015.07.013>

Cook, C. N., Hockings, M. and Carter, R. W. 2010. Conservation in the dark? The information used to support management decisions. Frontiers in Ecology and the Environment 8, 4: 181-186. <https://doi.org/10.1890/090020>

Cook, C. N., Carter, R. W., Fuller, R. A. and Hockings, M. 2012. Managers consider multiple lines of evidence important for biodiversity management decisions. Journal of Environmental Management 113: 341-346. <https://doi.org/10.1016/j.jenvman.2012.09.002>

Cook, C. N., Mascia, M. B., Schwartz, M. W., Possingham, H. P. and Fuller, R. A. 2013. Achieving conservation science that bridges the knowledge-action boundary. Conservation Biology 27, 4: 669-678. $<$ https://doi.org/10.1111/cobi.12050>

Cvitanovic, C., Fulton, C. J., Wilson, S. K., van Kerkhoff, L., Cripps, I. L. and Muthiga N. 2014. Utility of primary scientific literature to environmental managers: An international case study on coral-dominated marine protected areas. Ocean \& Coastal Management 102, Part A: 72-78. <https://doi.org/10.1016/j.ocecoaman.2014.09.003>

Cvitanovic, C., Hobday, A. J., van Kerkhoff, L. and Marshall, N. A. 2015. Overcoming barriers to knowledge exchange for adaptive resource management; the perspectives of Australian marine scientists. Marine Policy 52: 38-44. <https://doi.org/10.1016/j.marpol.2014.10.026>
Dicks, L. V. 2013. Bees, lies and evidence-based policy. Nature 494: 283. <https://doi.org/doi:10.1038/494283a>

Dicks, L. V, Abrahams, A., Atkinson, J., Biesmeijer, J., Bourn, N., et al. 2013. Identifying key knowledge needs for evidence-based conservation of wild insect pollinators: a collaborative cross-sectoral exercise. Insect Conservation and Diversity 6, 3: 435-446. $<$ https://doi.org/10.1111/j.1752-4598.2012.00221.x>

Dinerstein, E., Olson, D., Joshi, A., Vynne, C., Burgess, N. D., et al. 2017. An ecoregion-based approach to protecting half the terrestrial realm. Bioscience 67, 6: 534-545. <https://doi.org/10.1093/biosci/bix014>

Dudley, N. (ed.) 2008. Guidelines for Applying Protected Area Management Categories, IUCN, Gland, Switzerland IUCN. WITH Stolton, S., P. Shadie and N. Dudley (2013). IUCN WCPA Best Practice Guidance on Recognising Protected Areas and Assigning Management Categories and Governance Types, Best Practice Protected Area Guidelines Series No. 21. IUCN, Gland, Switzerland. Available at <https://portals.iucn.org/library/sites/library/files/documents/PAG-021.pdf>

Fazey, I., Fischer, J. and Lindenmayer, D. B. 2005. What do conservation biologists publish? Biological Conservation 124, 1: 63-73. <https://doi.org/10.1016/j.biocon.2005.01.013>

Fuller, R. A., Lee, J. R. and Watson, J. E. M. 2014. Achieving open access to conservation science. Conservation Biology 28, 6: 1550-1557. <https://doi.org/10.1111/cobi.12346>

Gardner, C. J., Nicoll, M. E., Mbohoahy, T., Oleson, K. L. L., Ratsifandrihamanana, A. N., et al. 2013. Protected areas for conservation and poverty alleviation: Experiences from Madagascar. Journal of Applied Ecology 50, 6: 1289-1294. <https://doi.org/10.1111/1365-2664.12164>

Gargouri, Y., Hajjem, C., Larivière, V., Gingras, Y., Carr, L., et al. 2010. Self-selected or mandated, open access increases citation impact for higher quality research. PLOS ONE 5, 10: e13636. <https://doi.org/10.1371/journal.pone.0013636>

Gibbons, P., Zammit, C., Youngentob, K., Possingham, H. P., Lindenmayer, D. B., et al. 2008. Some practical suggestions for improving engagement between researchers and policy-makers in natural resource management. Ecological Management \& Restoration 9, 3: 182-186. $<$ https://doi.org/10.1111/j.1442-8903.2008.00416.x>

Giehl, E. L. H., Moretti, M., Walsh, J. C., Batalha, M. A. and Cook, C. N. 2017. Scientific evidence and potential barriers in the management of Brazilian protected areas. PLOS ONE 12, 1: e0169917. <https://doi.org/10.1371/journal.pone.0169917>

Gossa, C., Fisher, M. and Milner-Gulland, E. J. 2015. The research-implementation gap: how practitioners and researchers from developing countries perceive the role of peer-reviewed literature in conservation science. Oryx 49, 1: 1-8. <https://doi.org/10.1017/s0030605313001634>

Griffiths, R. 2004. Mismatches between conservation science and practice. Trends in Ecology \& Evolution 19, 11: 564-565. <https://doi.org/10.1016/j.tree.2004.09.008>

Habel, J. C., Gossner, M. M., Meyer, S. T., Eggermont, H., Lens, L., et al. 2013. Mind the gaps when using science to address conservation concerns. Biodiversity and Conservation 22, 10: 2413-2427. <https://doi.org/10.1007/s10531-013-0536-y>

Haddaway, N. R. and Bayliss, H. R. 2015. Shades of grey: Two forms of grey literature important for reviews in conservation. Biological Conservation 191: 827-829. <https://doi.org/10.1016/j.biocon.2015.08.018>

Hambler, C. and Canney, S. M. 2013. Conservation. Cambridge University Press, Cambridge, UK.

Heiberger, R. M. and Robbins, N. B. 2014. Design of diverging stacked bar charts for likert scales and other applications. Journal of Statistical Software 57, 5: 1-32. <https://doi.org/10.18637/jss.v057.i05>

Hulme, P. E. 2014. Bridging the knowing-doing gap: know-who, know-what, knowwhy, know-how and know-when. Journal of Applied Ecology 51, 5: 1131-1136. <https://doi.org/10.1111/1365-2664.12321>

Jenkins, C. N. and Joppa, L. 2009. Expansion of the global terrestrial protected area system. Biological Conservation 142, 10: 2166-2174. <https://doi.org/10.1016/j.biocon.2009.04.016> 
Keene, M. and Pullin, A. S. 2011. Realizing an effectiveness revolution in environmental management. Journal of Environmental Management 92, 9: 2130-2135. <https://doi.org/10.1016/j.jenvman.2011.03.035>

Knight, A. T., Cowling, R. M., Rouget, M., Balmford, A., Lombard, A. T. and Campbell, B. M. 2008. Knowing but not doing: Selecting priority conservation areas and the research-implementation gap. Conservation Biology 22, 3: 610-617. <https://doi.org/10.1111/j.1523-1739.2008.00914.x>

Kremen, C., Cameron, A., Moilanen, A., Phillips, S. J., Thomas, C. D., et al. 2008. Aligning conservation priorities across taxa in Madagascar with highresolution planning tools. Science 320, 5873: 222-226. <https://doi.org/10.1126/science.1155193>

Kuebbing, S. E., Nuñez, M. A. and Simberloff, D. 2013. Current mismatch between research and conservation efforts: The need to study co-occurring invasive plant species. Biological Conservation 160: 121-129. <https://doi.org/10.1016/j.biocon.2013.01.009>

Lane, J. 2010. Let's make science metrics more scientific. Nature 464, 7288: 488-489.<https://doi.org/10.1038/464488a>

Laurance, W. F., Koster, H., Grooten, M., Anderson, A. B., Zuidema, P. A., et al. 2012. Making conservation research more relevant for conservation practitioners. Biological Conservation 153: 164-168. <https://doi.org/10.1016/j.biocon.2012.05.012>

Mace, G. M. 2014. Whose conservation? Science 345, 6204: 1558-1560. <https://doi.org/10.1126/science.1254704>

Marvier, M. 2014. New conservation is true conservation. Conservation Biology 28, 1: 1-3. <https://doi.org/10.1111/cobi.12206>

Matzek, V., Covino, J., Funk, J. L. and Saunders, M. 2014. Closing the knowing-doing gap in invasive plant management: Accessibility and interdisciplinarity of scientific research. Conservation Letters 7, 3: 208-215. <https://doi.org/10.1111/conl.12042>

Matzek, V., Pujalet, M., Cresci, S. and Lockwood, J. 2015. What managers want from invasive species research Versus what they get. Conservation Letters 8, 1: 33-40. <https://doi.org/10.1111/conl.12119>

Milner-Gulland, E. J., Fisher, M., Browne, S., Redford, K. H., Spencer, M. and Sutherland, W. J. 2010. Do we need to develop a more relevant conservation literature? Oryx 44, 1: 1-2. <https://doi.org/10.1017/s0030605309991001>

Milner-Gulland, E. J., Barlow, J., Cadotte, M. W., Hulme, P. E., Kerby, G. and Whittingham, M. J. 2012. Ensuring applied ecology has impact. Journal of Applied Ecology 49, 1: 1-5. <https://doi.org/10.1111/j.1365-2664.2011.02102.x>

Molloy, J. C. 2011. The open knowledge foundation: Open data means better science. PLoS Biology 9, 12: e1001195. <https://doi.org/10.1371/journal.pbio.1001195>

Neßhöver, C. and Timaeus, J. 2013. Improving the science-policy interface of biodiversity research projects. GAIA 22, 2: 99-103. <https://doi.org/10.14512/gaia.22.2.8>

Niyazov, Y., Vogel, C., Price, R., Lund, B., Judd, D., et al. 2016. Open access meets discoverability: Citations to articles posted to Academia.edu. PLOS ONE 11, 2: e0148257. <https://doi.org/10.1371/journal.pone.0148257>

Pooley, S. P., Mendelsohn, J. A. and Milner-Gulland, E. J. 2014. Hunting down the chimera of multiple disciplinarity in conservation science. Conservation Biology 28, 1: 22-32. <https://doi.org/10.1111/cobi.12183>

Poudyal, M., Ramamonjisoa, B. S., Hockley, N., Rakotonarivo, O. S., Gibbons, J. M., Mandimbiniaina, R., Rasoamanana, A. and Jones, J. P. G. 2016. Can REDD+ social safeguards reach the "right" people? Lessons from Madagascar. Global Environmental Change 37: 31-42. <https://doi.org/10.1016/j.gloenvcha.2016.01.004>

Pretty, J., Sutherland, W. J., Ashby, J., Auburn, J., Baulcombe, D., et al. 2010. The top 100 questions of importance to the future of global agriculture. International Journal of Agricultural Sustainability 8, 4: 219-236. <https://doi.org/10.3763/ijas.2010.0534>

Pullin, A. S., Knight, T. M., Stone, D. A. and Charman, K. 2004. Do conservation managers use scientific evidence to support their decision-making? Biological Conservation 119, 2: 245-252. <https://doi.org/10.1016/j.biocon.2003.11.007>

R Core Team. 2017. R: A language and environment for statistical computing. Vienna, Austria: R Foundation for Statistical Computing. Retrieved from $<$ https://www.r-project.org/>
Raik, D. B., Wilson, A. L. and Decker, D. J. 2008. Power in natural resources management: an application of theory. Society \& Natural Resources 21, 8: 729-739. <https://doi.org/10.1080/08941920801905195>

Rich, R. F. 1997. Measuring knowledge utilization: processes and outcomes. Knowledge and Policy 10, 3: 11-24. <https://doi.org/10.1007/BF02912504>

Robinson, J. G. 2006. Conservation biology and real-world conservation. Conservation Biology 20, 3: 658-669. <https://doi.org/10.1111/j.1523-1739.2006.00469.x>

Roux, D. J., Rogers, K. H., Biggs, H. C., Ashton, P. J. and Sergeant, A. 2006. Bridging the science-management divide: Moving from unidirectional knowledge transfer to knowledge interfacing and sharing. Ecology and Society 11, 1 \#4. Available at <http://www.ecologyandsociety.org/vol11/iss1/art4/>

Roux, D. J., Kingsford, R. T., McCool, S. F., McGeoch, M. A. and Foxcroft, L. C. 2015. The role and value of conservation agency research. Environmental Management 55, 6:1232-1245. <https://doi.org/10.1007/s00267-015-0473-5>

Rudd, M. A., Beazley, K. F., Cooke, S. J., Fleishman, E., Lane, D. E., et al. 2011. Generation of priority research questions to inform conservation policy and management at a national level. Conservation Biology 25, 3: 476-484. <https://doi.org/10.1111/j.1523-1739.2010.01625.x>

Seavy, N. E. and Howell, C. A. 2009. How can we improve information delivery to support conservation and restoration decisions? Biodiversity and Conservation 19, 5: 1261-1267. <https://doi.org/10.1007/s10531-009-9752-x>

Segan, D. B., Bottrill, M. C., Baxter, P. W. J. and Possingham, H. P. 2011. Using conservation evidence to guide management. Conservation Biology 25, 1: 200-202. <https://doi.org/10.1111/j.1523-1739.2010.01582.x>

Shafer, C. L. 2015. Cautionary thoughts on IUCN protected area management categories V-VI. Global Ecology and Conservation 3: 331-348. <https://doi.org/10.1016/j.gecco.2014.12.007>

Soulé, M. E. 1985. What is conservation biology? Bioscience 35, 11: 727-734. $<$ https://doi.org/10.2307/1310054>

Sutherland, W. J., Pullin, A. S., Dolman, P. M. and Knight, T. M. 2004. The need for evidence-based conservation. Trends in Ecology \& Evolution 19, 6: 305-8. <https://doi.org/10.1016/j.tree.2004.03.018>

Sutherland, W. J., Armstrong-Brown, S., Armsworth, P. R., Brereton, T., Brickland, J., et al. 2006. The identification of 100 ecological questions of high policy relevance in the UK. Journal of Applied Ecology 43, 4: 617-627. <https://doi.org/10.1111/j.1365-2664.2006.01188.x>

Sutherland, W. J., Adams, W. M., Aronson, R. B., Aveling, R., Blackburn, T. M., et al. 2009. One hundred questions of importance to the conservation of global biological diversity. Conservation Biology 23, 3: 557-67. $<$ https://doi.org/10.1111/j.1523-1739.2009.01212.x>

Sutherland, W. J., Bellingan, L., Bellingham, J. R., Blackstock, J. J., Bloomfield, R. M. et al. 2012. A collaboratively-derived science-policy research agenda. Plos ONE 7, 3: e31824. <https://doi.org/10.1371/journal.pone.0031824>

Sutherland, W. J. and Wordley, C. F. R. 2017. Evidence complacency hampers conservation. Nature Ecology and Evolution 1, 9: 1215-1216. $<$ https://doi.org/10.1038/s41559-017-0244-1>

Walsh, J. C., Dicks, L. V and Sutherland, W. J. 2015. The effect of scientific evidence on conservation practitioners' management decisions. Conservation Biology 29, 1: 88-98. <https://doi.org/10.1111/cobi.12370>

Watermeyer, R. 2014. Issues in the articulation of 'impact': the responses of UK academics to 'impact' as a new measure of research assessment. Studies in Higher Education 39, 2: 359-377. <https://doi.org/10.1080/03075079.2012.709490>

Watson, J. E. M., Dudley, N., Segan, D. B. and Hockings, M. 2014. The performance and potential of protected areas. Nature 515: 67-73. $<$ https://doi.org/10.1038/nature13947>

Young, J. C., Waylen, K. A., Sarkki, S., Albon, S., Bainbridge, I., et al. 2014. Improving the science-policy dialogue to meet the challenges of biodiversity conservation: Having conversations rather than talking at one-another. Biodiversity and Conservation 23, 2: 387-404. <https://doi.org/10.1007/s10531-013-0607-0>

Young, K. D. and Van Aarde, R. J. 2011. Science and elephant management decisions in South Africa. Biological Conservation 144, 2: 876-885. <https://doi.org/10.1016/j.biocon.2010.11.023> 


\section{SUPPLEMENTARY MATERIAL.}

Available online only.

Table S1. Information about the protected areas in Madagascar considered in this work, the IUCN category (cat), size (area), type of organisation (org) leading the management, and the number of respondents who completed the questionnaire (quest) or took part in a semi-structured interview (int).

Supplementary Material 2. Understanding the use of research results in protected area management in Madagascar. A questionnaire.

Figure S3. The location of all the protected areas in Madagascar (green dots indicate protected areas for which we have responses to the questionnaire (left) or the interviews (right). The size of the mark corresponds to the number of responses from a PA (the maximum was 4). Red dots indicate protected areas from which we have no response).

Table S4. Resources which can help managers access research results. 